Review

\title{
The Role of Sox Genes in Lung Morphogenesis and Cancer
}

\author{
Yongzhao Zhu ${ }^{1,2}$, Yong $\mathrm{Li}^{1}{ }^{1}$, Jun Wei ${ }^{2, *}$ and Xiaoming Liu ${ }^{1, *}$
}

1 Key Laboratory of the Ministry of Education for Conservation and Utilization of Special Biological Resources in Western China, College of Life science, Ningxia University, Yinchuan 750021, China; E-Mails: btxnxu05@163.com (Y.Z.); liyong7732@126.com (Y.L.)

2 Institute of Stem Cell Research, General Hospital of Ningxia Medical University, Yinchuan 750004, China

* Authors to whom correspondence should be addressed; E-Mails: lydiajunwei@hotmail.com (J.W.); 1xm1966@nxu.edu.cn or erc1080@gmail.com (X.L.); Tel.: +86-951-674-3751 (J.W.); +86-951-206-2037 (X.L); Fax: +86-951-206-2699 (X.L.).

Received: 25 September 2012; in revised form: 26 October 2012 / Accepted: 14 November 2012 / Published: 26 November 2012

\begin{abstract}
The human lung consists of multiple cell types derived from early embryonic compartments. The morphogenesis of the lung, as well as the injury repair of the adult lung, is tightly controlled by a network of signaling pathways with key transcriptional factors. Lung cancer is the third most cancer-related death in the world, which may be developed due to the failure of regulating the signaling pathways. Sox (sex-determining region Y (Sry) box-containing) family transcriptional factors have emerged as potent modulators in embryonic development, stem cells maintenance, tissue homeostasis, and cancerogenesis in multiple processes. Recent studies demonstrated that the members of the Sox gene family played important roles in the development and maintenance of lung and development of lung cancer. In this context, we summarize our current understanding of the role of Sox family transcriptional factors in the morphogenesis of lung, their oncogenic potential in lung cancer, and their potential impact in the diagnosis, prognosis, and targeted therapy of lung cancer.
\end{abstract}

Keywords: Sox; lung cancer; lung morphogenesis; transcriptional factors 


\section{Introduction}

Lung cancer is an aggressive cancer type and is the third most common cancer in the world. As a leading cause of cancer-associated mortality, it causes over 160,000 deaths annually in the United States alone [1]. Based on its clinical, histological, molecular, and/or neuro-endocrinological characteristics, lung cancer was classified into two main types: non-small cell lung cancer (NSCLC) and small cell lung cancer (SCLC). NSCLC was further subdivided into large-cell carcinoma (including large-cell neuroendocrine lung cancers), bronchoalveolar lung cancer, adenocarcinoma (AC), squamous cell carcinoma (SCC), and mixed histologic types (e.g., adenosquamous carcinoma) [1,2]; this represents $80 \%-85 \%$ of lung cancer cases, while SCLC represents the remaining $15 \%-20 \%$ cases $[1,2]$. Owing to its high rate of occurrence with a very poor prognosis relative to other cancer types, lung cancer has recently received increasing public attention.

A large body of cellular signaling pathways has been demonstrated to be involved in the cancerogenesis of various types of cancer, including lung cancer, and some of the signaling molecules are targets for the development of drugs in lung cancer therapy [3]. The vascular endothelial growth factor (VEGF) and epidermal growth factor receptor (EGFR) are of two molecules extensively studied for developing novel agents in the targeted therapy of lung cancer [4]. Therefore, understanding the signaling pathways and identifying the key regulators in both lung development and cancerogenesis may provide an insight into the molecular mechanisms of lung cancerogenesis and create new targets for treatment.

Increasing lines of evidence has shown that lung morphogenesis is controlled by many signaling pathways and transcriptional factors, such as the Wnt signaling pathway, growth factors, and transcriptional factors including: the T-cell factor (TCF) and sex-determining region Y (Sry) box-containing factor (Sox) [5]. These signaling molecules have also been discovered to share diverse roles in lung cancer, despite the fact that the cancerogenesis of lung is a multiple progress with more tendency to be influenced through oncogenes, tumor suppressor genes, key signal transduction cascades, microRNA (miRNA), as well as genetic mutation such as gene amplification and epigenetic modification [6-9]. The Sox genes encode a family of high-mobility groups that are a family of transcriptional factors and have emerged as potent modulators involved in orchestrating embryonic development and cell fate, organogenesis, stem cells maintenance, and cancerogenesis in multiple processes. The presented review aims to summarize the roles of Sox transcriptional factors in the morphogenesis and malignancy of the lung.

\section{Sox Transcriptional Factors}

With the discovery of the first Sox gene (sex-determining region Y, Sry) at the end of 20th century, over twenty different Sox genes have been identified in mammalians [10,11]. They all share a noncanonical 79 amino acid DNA-binding domain known as the high mobility group (HMG) box domain. On basis of the sequence comparison of the HMG box domain, Sox genes are currently classified into eight groups (Sox A-H); Sox proteins with the same group share a high level of identity both within and outside of the HMG box domain, whereas proteins from different groups share partial identities [12]. As transcriptional factors, Sox proteins gain the ability to bind DNA through recognizing of a consensus hexameric core sequence $5^{\prime}-(\mathrm{A} / \mathrm{T})(\mathrm{A} / \mathrm{T}) \mathrm{CAA}(\mathrm{A} / \mathrm{T})-3^{\prime}$, although the consensus sequence 
is not the only factor that influences the DNA binding of Sox proteins [13-15]. Unlike most other transcriptional factors, the members of Sox family prefer to bind to the minor groove of DNA by which the local chromatin space structure will be changed; this may provide a mechanism of enhanceosome formation. Owing to their lower affinity of DNA binding, Sox proteins are widely believed to team up with other transcriptional factors, such as POU (Oct3/4), zinc finger proteins, basic helix-loop-helix and leucine zipper proteins for functioning properly [16-18]. Increased direct and circumstantial evidence has proved that Sox proteins played a crucial role in multiple development process, including embryonic development, disease, and cancer [19,20]. In this process, they were capable of regulating target genes expression as transcriptional activators or repressors depend on both of the cellular and target gene contexts [21]. Furthermore, the activity of Sox proteins could also be modulated during the processes of phosphorylation, sumoylation and/or ubiquitination [22,23].

\section{Sox Gene and Lung Morphogenesis}

Lung originates initially from the foregut of early embryo and subsequently differentiates into multiple lineages of lung cell types through sequential periods of pseudoglandular, canalicular, terminal saccular, and alveolar stages. Several signaling pathways, as well as transcriptional factors, growth factors, extracellular matrix, and miRNA have been identified to contribute to the development and maturation of lung [5]. To date, at least four members from Sox gene family are known to be involved in lung organogenesis, they are Sox2, Sox9, Sox11 and Sox17 genes [5,24-29].

Sox 2 is expressed from foregut to mature lung in a cyclic manner except for alveolus, which plays a crucial role in proliferation and differentiation of respiratory epithelial, trachea, airway branching, and Clara cells [5,28,30,31]. Previous studies in transgenic mice that express a doxycycline inducible Sox2 in the airway epithelium, demonstrated that Sox 2 played a critical role in branching morphogenesis of the bronchial tree and the differentiation of airway epithelium [30]. In addition, selectively deleted Sox2 gene in Clara cells by Clara cell secretory protein (CCSP) promoter-derived Cre recombinase, led the progressive loss of ciliated, Clara and goblet cells in bronchiolar epithelium after the birth of an animal. This also caused a loss of the ability of goblet cell differentiation and mucus production in response to allergen in the respiratory epithelium [31]. A recent study performed in the same group, which utilized a mouse model, demonstrated that Sox 2 was conditionally expressed in a subset of respiratory cells under the CCSP promoter, and that Sox 2 was capable of promoting the proliferation of nonciliated airway epithelial cells, accompanied with increased expression of cell cycle genes FoxM1, Cyclin A2, Cyclin B2 and Cyclin D1 in mice [28]. Therefore, defining the CCSP-Cre-derived cell population may facilitate our understanding of the roles of Sox 2 in the morphogenesis of lung, and the pathogenesis of lung diseases. A subset of reprogrammed alveolar epithelial cells, which consequentially produces hyperplastic lesions with markers of conducting airway epithelium, was also observed in the above study, despite the fact that Sox2 alone was insufficient to transform epithelial cells into tumors [28]. In addition to the indispensable roles in the normal development of lung buds and the differentiation of both tracheal mesenchyme and epithelium, Sox 2 has been demonstrated to be associated with the epithelial cell proliferation and repair of tracheal epithelium following the injury [32].

Highly expressed Sox9 was found throughout lung morphogenesis as a downstream gene of Sonic Hedgehog (Shh) modulated by bone morphogenesis protein 4 (Bmp4) and Noggin. These are required 
for formation and patterning of tracheal cartilage by a mechanism of fibroblast growth factor 18 (FGF18) mediated controlling of Sox 9 expression level and pattern [26,33]. Nevertheless, the specific inactivation of Sox 9 in respiratory epithelial cells could not alter lung structure, postnatal survival, or repair oxygen injury, thus indicating that Sox9 might not play essential role in the respiratory epithelial cells [34].

Sox11 gene has been suggested to be involved in a wide range of organogenesis and has a key function in tissue remodeling including the lung. Mice deficient in Sox11 immediately die after birth caused by the significant hypoplasia of lung and other tissue defects [29].

Sox 17 is one of the most extensively studied Sox transcriptional factors in the lung development, which was found to be expressed in respiratory epithelial cells of the fetal lung at embryonic day 18 and is restricted primarily to ciliated cell in the postnatal and adult lung [25,27,35,36]. Of note, however, Sox 17 mRNA has not been detected in the lung epithelium [27], and a mouse model ectopically expressing Sox17 in lung epithelium also showed that the expression of Sox17 was not in the epithelium but restricted to the pulmonary mesenchyme of the lung (especially the endothelium of the developing lung) [25]. Sox 17 is required for the formation of early endoderm, activates the cell cycle, and reinitiates multipotent progenitor cell behavior in mature lung cells, as well as other development processes such as cardiovascular development, fetal hematopoietic stem cell maintenance, and angiogenesis [25,35,37-40]. Conditional expression of Sox17 in mature respiratory epithelial cells of mice showed formation of hyperplastic clusters of cells and respecification of alveolar progenitor cells toward proximal airway lineages [25,27]. However, ectopic expression of Sox17 in the epithelial cells of the mouse embryonic lung led to inhibiting peripheral epithelial cell differentiation and disrupted branching morphogenesis [25]. Additionally, Sox 17 has been found to have a potential to reinitiate multipotent progenitor cell behavior, and it could activate the cell cycle in mature lung cells by inducing cell proliferation and the expression of the progenitor cell marker Sca-1 and cell cycle gene Cycling D1, as well as reducing the expression of TGF-beta1 responsive inhibitors, p15, p21 and p57, while inhibiting TGF-beta1 and Smad3 transcriptional activity [25].

\section{Sox Genes and Lung Cancer}

\subsection{Sox Genes and Cancers}

Improper regulation of Sox genes have been demonstrated to be associated with cancerous development of various types of cancer [20], such as gastric cancer [41,42], brain tumors [43,44], ovarian cancer [45], adenocarcinoma [46-49], hepatocarcinoma [50], breast cancer [51-53], melanomas [54], prostate cancer [55-58], colon carcinoma [59], and the lung cancer [18,36,60-69]. The role of the Sox gene family in the cancerogenesis has been attributed to their properties involving in the regulation of cell differentiation, proliferation, and survival in multiple essential processes. Although most Sox genes show a property of oncogenes in many types of cancers, different members of the Sox gene family may play distinct roles in various types of cancers; some of them show an oncogenic potential to promote the development of cancers [70], whereas others may behave as a tumor suppressor gene to block the growth of carcinomas [71,72]. For instance, Sox9 plays broadly roles in cancerogenesis and is overexpressed in many types of human cancers, where Sox9 exhibits pro-oncogenic properties of promoting cell proliferation, inhibiting cell senescence, and collaborating 
with other oncogenes in neoplastic transformation [73]. The expression of Sox 9 was upregulated in hepatocellular carcinoma and lung adenocarcinoma, and it was associated with tumor progression and poor prognosis of the diseases [46,50]. On the other hand, a downregulated expression of Sox 7 in lung adenocarcinoma was a poor prognosis marker for patients with this type of cancer [47]. Interestingly, the identical Sox gene exhibits a dual functional role in cancers, which may play opposite functions in different cancer types. For example, Sox 2 was overexpressed in glioblastoma multiform as compared to normal cell lines. Such ectopic expression was sufficient to induce invasion and migration of glioma cells, suggesting that it contributed to tumor development in this study [74]. In contrast to the characteristic of oncogene, Sox 2 was capable of inducing cell-cycle arrest and apoptosis in gastric epithelial cells, and the loss of Sox 2 expression might be relevant to gastric cancerogenesis and poor prognosis [41]. Similarly, an upregulation of Sox9 gene was capable of inhibiting the growth of melanomas [54]. In glioma cells, however, a downregulation of Sox9 expression could inhibit the cell growth, induce the cell arrest and enhance the apoptosis [70]. Furthermore, Sox genes might express in malignant cells to specifically stimulate the immune system in order to produce their relevant antibodies. This could be utilized as an index for diagnosis and therapy for cancers [64]. Table 1 lists the Sox genes related to lung cancer. Similarly seen in other types of cancer, the role of Sox genes and proteins have also been demonstrated that they play roles in the oncogenesis, tumor suppression, and cancer stem cells' (CSCs) maintenance in lung cancer. More important, the same Sox gene shows distinct functions in diverse types of lung cancer, indicating that different types of lung cancer possess specific cell contexts $[68,69,75,76]$.

Table 1. Evidence and role of Sox family transcriptional factors in lung cancer.

\begin{tabular}{cl}
\hline Sox genes & \multicolumn{1}{c}{ Evidence or role in lung cancer } \\
\hline Sox1 & Autoantibody to Sox1 detected in the serum of patients with SCLC [67,77-79]. \\
Sox2 & $\begin{array}{l}\text { Autoimmunity found in patients with SCLC [64,67,78,79]; strongly expressed in both of NSCLC } \\
\text { and SCLC tumor cells determined by IHC and/or FISH assays [62,63,66,76]; overexpression leads to } \\
\text { lung cancer with poor prognostic outcome [48,80]; gene mutation(s) observed in SCLC [66]; } \\
\text { inhibition of expression in cancer stem cells suppress the growth and metastasis of lung cancer [69]. }\end{array}$ \\
\hline Sox3 & Autoantibody detected in patients with SCLC [67,78,79]; gene mutation(s) observed in SCLC [66]. \\
\hline & $\begin{array}{l}\text { Autoantibody detected in the serum of patients with SCLC [81]; strong expression detected in } \\
\text { SCLC tumor cells by IHC [61]; gene mutations found in SCLC and might be correlated with the } \\
\text { lung cancerogenesis and tumor metastasis [18,65,66,82]. }\end{array}$ \\
\hline Sox5 & Gene mutation (s) determined in SCLC [66] \\
\hline Sox6 & Gene mutation (s) observed in SCLC [66] \\
\hline Sox7 & Downregulation was correlated with a poor prognosis in patients with lung AC [47]. \\
\hline Sox9 & $\begin{array}{l}\text { Overexpression promoted lung adenocarcinoma cell proliferation [46]; gene mutation(s) detected } \\
\text { in SCLC [66]. }\end{array}$ \\
\hline Sox11 & Gene mutation (s) found in SCLC [66] \\
\hline Sox14 & Gene mutation (s) observed in SCLC [66] \\
\hline Sox17 & Gene mutation (s) detected in SCLC [66] \\
\hline Sox18 & Heterogeneous methylation was found in the promoter of gene [60]. \\
\hline Sox21 & Autoantibody detected in the serum of patients with SCLC [67,78,79]
\end{tabular}




\subsection{Oncogenic Potential of Sox Genes in Lung Cancer}

A number of studies have shown strong expression of Sox2, Sox4, and Sox11 in most SCLCs [61]. This implied the potential roles for the Sox transcriptional factors in this type of lung cancer. Among them, the role of Sox 2 gene in lung cancer is the one best recognized, which is relevant to aggressive tumor behavior, poor outcome, and/or the increasing risk of recurrence $[48,62,76,80]$. Sox 2 was found to be a potential cell-lineage gene highly expressed in both of the human SCLC $[66,80]$ and NSCLC $[63,75,83]$. Previous studies in mice revealed that the high level of Sox 2 expression in lung epithelial cells was favorable to promote lung cancerogenesis [80]. Such findings were supported by the studies in patients with lung cancer; high expression of Sox 2 was detected in lung SCC and stage I lung cancer of these patients, in which the Sox2 was found to be in concert with p63 to influence the tumor differentiation $[48,83]$. Additionally, autoantibodies against Sox 2 were also detected in sera from SCLC patients $[48,80,83,84]$. The potential role of Sox 2 gene in lung cancer was further supported by a recent finding of identification of Sox 2 as a frequently amplified gene [66]. In this study, Rudin and colleagues performed a comprehensive genomic analysis to identify new recurrent somatic mutations in SCLC; twenty-two significantly mutated genes were identified, including several members of Sox family of genes (Sox3, Sox4, Sox 5, Sox6, Sox9, Sox 11, Sox 14 and Sox 17) in SCLC. In addition, Sox 2 amplification was found in approximately $27 \%$ of the SCLC samples determined by immunohistochemical staining (IHC) or fluorescent in situ hybridization (FISH) assays. Moreover, Sox2 expression inhibited by shRNAs led to a decreased proliferation of Sox2-amplified SCLC cells. These results suggest that Sox2 gene may be a potential target for therapeutic intervention in SCLC.

Aside from the Sox2, the expression of Sox 4 was also elevated in several types of cancer $[85,86]$, in which lung cancer had the greatest levels of Sox 4 expression $[61,65]$. Through in vitro knocking out the expression of Sox4, the induction of apoptosis and growth suppression in cancer cells were demonstrated $[55,87,88]$. These studies clearly indicated a correlation of Sox 4 with lung cancer. The relationship of Sox4 to cancerogenesis of lung cancer was further attested by a polymorphic study in patients with NSCLC. In this study, a gradual increased mutation rate with the pathological stages of NSCLC were observed, suggesting that Sox 4 gene mutation was correlated with the pathological stages of this type of cancer, even though no association of Sox4 gene mutation with pathology histological types of tumor was determined [18].

Other than the Sox 2 and Sox4, Sox 9 and Sox 18 also showed oncogenetic properties in lung cancer. Recent studies validated that Sox 9 was capable of promoting lung AC proliferation potential through the regulation of the expressions of $\mathrm{p} 21$ and CDK4. This suggested that Sox9 was a new hallmark of lung $\mathrm{AC}$, in which Sox 9 might contribute to the gain of tumor growth potential [46]. The aberrant methylation in the promoter of Sox 18 gene in lung cancer also suggested that inactivation of Sox 18 expression might play a crucial role in the malignance [89]. Four Sox family members (Sox2, Sox4, Sox9, and Sox11) are currently determined with high levels of expression in various types of lung cancers, but the patterns of their expression among the lung cancer types are strongly different, particularly in NSCLC, in which increased levels of Sox 4 expression is preferentially in ACs. On the other hand, high levels of Sox 2 and Sox9 are more commonly seen in the SCC type [61].

Apart from their oncogenic properties, Sox transcriptional factors also exert inhibitory functions in the development and progression in a variety of cancers. Presently, the tumor suppressor characteristics 
of Sox proteins in lung cancer are mainly focused on members of Sox group F (Sox7, Sox 17, Sox 18). A decreased expression of Sox7 determined by quantitative real-time reverse transcription polymerase chain reaction (qRT-PCR) and/or IHC in lung AC, has demonstrated to be associated with poor differentiation of cancer cells and a better overall survival rate. This suggests Sox 7 may serve as a prognostic biomarker for lung AC [47].

Genetic mutations, as well as epigenetic modifications have been increasingly recognized to play major roles in the cancerogenic process. Table 2 lists some of genetic and epigenetic abnormalities of Sox genes and their clinical relevance in cancers, particularly in the lung cancer. In an epigenetic study, promoter methylation of Sox 17 promoter was found in $60.2 \%$ of primary human lung cancer specimens [36]. Owing to aberrant and heterogeneous methylation in their promoter CpG islands, both expressions of Sox17 and Sox 18 were silenced in SCLC [36] and NSCLC [60]. In addition, colony formation assays further demonstrated that expression of Sox17 inhibited lung cancer cell proliferation and differentiation, in part through a suppression of Wnt signal pathway [36]. Moreover, in addition to a biomarker of poor prognosis in lung cancer, Sox 2 amplification and upregulation were frequent events in lung SCC, which were associated with indicators of favorable prognosis in this study [68].

Table 2. Genetic and epigenetic abnormalities of Sox genes and their clinical relevance in cancers.

\begin{tabular}{|c|c|c|c|}
\hline Sox gene & Abnormality or mutation & Potential clinical implication & Reference \\
\hline \multirow[t]{2}{*}{ Sox 2} & Gene amplification & Associated with the prognosis of SCLC and lung SCC & {$[61,66,68,74,84]$} \\
\hline & Gene methylation & $\begin{array}{l}\text { Associated with the progression of malignant } \\
\text { gliobastoma and gastric cancer }\end{array}$ & {$[41,74]$} \\
\hline Sox3 & N161K mutation & Associated with the progression of SCLC & {$[66]$} \\
\hline \multirow[t]{4}{*}{ Sox4 } & Point mutations & Correlated with the stages of NSCLC & {$[18]$} \\
\hline & Gene amplification & Associated with the prognosis of SCLC and NSCLC & {$[61,65]$} \\
\hline & S395X mutation & Increase the ability of transform in cell line & {$[65]$} \\
\hline & D398V mutation & Found in SCLC samples & {$[66]$} \\
\hline Sox 5 & V316F, R547L mutations & Found in SCLC samples & {$[66]$} \\
\hline Sox6 & D494Y, G728V mutations & Found in SCLC samples & {$[66]$} \\
\hline Sox 7 & $\begin{array}{l}\text { Methylation of } \mathrm{CpG} \text { islands near } \\
\text { the gene promoter }\end{array}$ & $\begin{array}{l}\text { Correlated with the poor prognosis of patients with } \\
\text { myelodysplastic syndrome }\end{array}$ & {$[90]$} \\
\hline \multirow[t]{2}{*}{$\operatorname{Sox} 9$} & S64R mutation & Found in SCLC samples & {$[66]$} \\
\hline & $\begin{array}{l}\text { CpG methylation of } \\
\text { promoter gene }\end{array}$ & $\begin{array}{l}\text { Associated with progression of bladder cancer and } \\
\text { gastric cancer }\end{array}$ & {$[42,72]$} \\
\hline \multirow[t]{2}{*}{ Sox11 } & Gene amplification & Associated with the prognosis of SCLC & {$[61]$} \\
\hline & E101* nonsense change & Found in SCLC samples & {$[66]$} \\
\hline Sox14 & M240I mutation & Found in SCLC samples & {$[66]$} \\
\hline Sox18 & Promoter gene CpG methylation & Found in NSCLC tissues & {$[60]$} \\
\hline
\end{tabular}

\section{Sox Gene and Lung Cancer Stem Cells}

Cancer stem cells (CSCs) are defined as a small subset cells within tumors which possess the capacity of self-renewal, potential differentiation, and give rise to heterogeneous cancer cell types [91]. CSCs 
thereby have the ability of initiation, maintenance, and recurrence of a tumor [92]. The isolation and characterization of lung stem and progenitor cells are an important step towards the understanding of pathogenesis of lung disease, as well as the identification of the target cells of transformation in lung cancerogenesis [93]. A pioneering study conducted by Kim et al. has identified bronchioalveolar stem cells (BASCs) in the distal lung [94]. This subset of population of stem cells resided at the bronchioalveolar duct junction, with a capacity to repair bronchiolar and alveolar injury and proliferate during epithelial cell renewal in vivo. Importantly, BASCs had an ability of expansion in response to oncogenic Kras in culture and in precursors of lung cancers in vivo, which was indicative of the putative cells of origin for lung adenocarcinoma, and a direct evidence of the existence of lung cancer stem cells [94]. The adult lung stem cells and characterization of lung cancer stem cells have been extensively reviewed recently [93].

Figure 1. Potential roles of Sox genes in the development of lung cancer by a mechanism of the interaction of Sox and Wnt signaling. In the cancerogenesis of lung cancer, Sox proteins could play a role in the cancerogenesis of lung cancer by either repressing (such as Sox17) canonical Wnt signaling or enhancing (such as Sox4) the Wnt signaling, by which the Wnt/ $\beta$-catenin signaling controls the determination of CSCs for proliferation, self-renewal and differentiation, and accordingly impacts the initiation, progression, and metastasis (EMT) of lung cancer through, in part, a mechanism of regulation of the expression of Wnt target genes, including those related to cell cycling, stem cell pluripotency, and EMT.

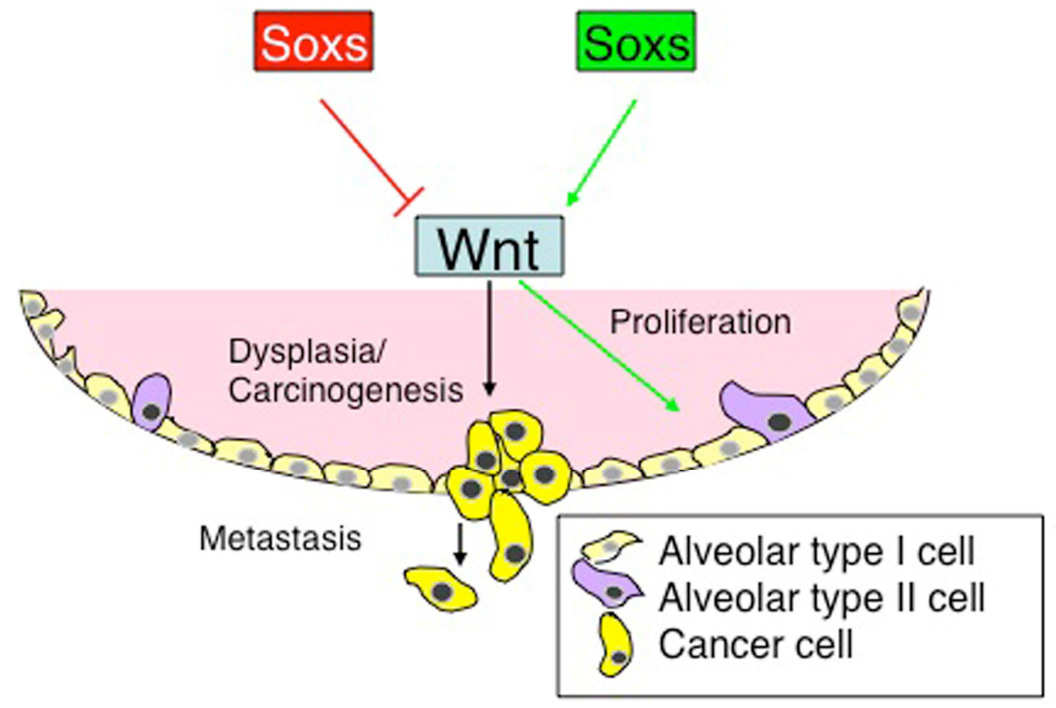

In addition to its pivotal role in the derivation and maintenance of embryonic stem cells (ES) and induced pluripotent stem cells (iPS), the Sox2 showed its potential to derive gastrointestinal CSCs $[95,96]$. As a stemness gene, Sox 2 plays an essential role in maintaining the stemness property of glioma-initiating cells (GICs), where the expression of Sox 2 gene could be induced by autocrine TGF- $\beta$ through its target gene, Sox4 [97]. The importance of Sox 2 in maintaining lung CSC has also been investigated by Xiang and coworkers [69]. In their study, the upregulation of Sox 2 and Oot4 in the side population (SP) cells of lung cancer led the cancer cells to shift to CSCs. On the other hand, knocking down Sox 2 expression showed a reduced ability of migration and enhanced apoptosis in these cells [69]. The molecular mechanism of Sox 2 gene in promoting development of lung cancer stem cells and 
enhancing the potential of cancerogenesis might be related to the elevation of the expression of oncogenes c-Myc, Wnt1, Wnt2 and Notch1 [62]. Indeed, increased expression of either Sox 2 or nuclear $\beta$-catenin was found to be associated with distant metastases of colon cancer [98]. In the lung, $\beta$-catenin was found to regulate basal progenitor cell fate and subsequent SCC progression by modulating epithelial-mesenchymal transition (EMT) [99]. Moreover, mutations in Wnt pathway components enable the leading of the constitutive signaling and have been linked to the cancerogenesis of many types of cancer [100,101]. Additionally, a recent work demonstrated that a combinatoral activation of both canonical Wnt signaling and Kras pathway showed a remarkable increase of lung cancer formation with a more progenitor-like phenotype [102,103]. Emerging evidence has also suggested a widespread role of Sox gene in modulating Wnt signaling in the development and in diseases, in which Sox proteins either repressed or activated Wnt signaling (Figure 1) [11]. It will be conceivable that a therapeutic strategy specifically targeting signaling molecules utilized by lung CSCs, such as the Sox gene, could be beneficial in treating a dreadful disease like lung cancer.

\section{Sox genes for Diagnosis and Therapeutic Targets in Lung Cancer}

Sox protein of members of the Sox B1 group (Sox1, Sox2, Sox3, Sox21) has been demonstrated to be highly immunogenic in patients with SCLC [78]. The autoantibody to these transcriptional factors was frequently and stably presented in the serum of patients, as compared with normal subjects. This suggests that Sox group B, except Sox14, may serve as serological markers for SCLC [67,78,79]. Moreover, aside from their diagnostic use, the determination of Sox group B1 antibodies was able to discriminate the difference between SCLC coupled with Lambert-Eaton myasthenic syndrome (LEMS) and nontumor LEMS, although it seemingly does not improve prognosis in SCLC [64,67]. Sox2 protein also was detected in NSCLC and SCC as a marker for diagnosis and therapeutic targets, even though it did not show a high sensitivity and specificity for SCC $[62,63,104]$. In addition, overexpression of Sox 4 was detected in all types of lung cancer, including SCLC and NSCLC, and the antigen peptide derived from Sox 4 was capable of activating $\mathrm{CD}^{+}$and $\mathrm{CD} 8^{+} \mathrm{T}$ cells recognizing Sox 4 positive lung tumor cells, by which Sox 4 might serve as a vaccine antigen candidate for the treatment of both SCLC and NSCLC [81]. These evidences clearly indicated that Sox proteins and autoantibodies might be effective molecular markers and/or therapeutic targets of lung cancer.

\section{Concluding Remarks}

The roles of Sox transcriptional factors in essential development and physiological processes have been rapidly elucidated since the discovery of their first member two decades ago. In this review, the potential role of Sox gene family members in lung cancer was emphasized by discussing current knowledge of the role of Sox transcriptional factors in lung development and lung cancer, as previously discussed. It is now unambiguous that the Sox family plays indispensable roles in lung morphogenesis, cancerogenesis, as well as lung CSC maintenance through a variety of mechanisms, such as epigenetic modification, interaction with Wnt signaling, and immune system modulation. It will be important to explore the association of the recently discovered mutations in Sox genes and their implication in varied subtypes of lung cancer. Moreover, the dual functional role of Sox family transcriptional factors in lung cancer implies a diverse function and mechanisms of Sox gene in cancerogenesis of lung cancer, which 
requires further investigation. Additionally, the specific expression of the Sox factor in lung cancer tissues and the autoantibody to Sox protein in the serum has provided a valuable target for diagnosis and the development of targeting agents for lung cancer. Of equal importance, the ability of Sox to induce antigen-specific T-cell response also offers a feasibility to develop vaccine-based immunotherapeutic strategies by which the comprehensive Sox-related anti-tumor immune response may be activated.

To date, however, only several Sox gene members have been unsystematically studied; it is a necessity to extensively investigate their roles in the essential development and diseases, as well as to further explore the roles of other Sox family members in this context, and the impact of genetic mutation and epigenetic modification of the Sox gene in lung cancer development. In spite of increasing evidence that suggests that Sox gene family members are correlated with the lung development and cancer formation at some extent, the underlying molecular mechanisms of Sox gene on lung morphogenesis and cancerogenesis have yet to be fully established.

\section{Acknowledgments}

This work was supported by Grants (Nos. of 31172278, 31260615 and 30960176) from National Natural Science Foundation of China.

\section{Conflict of Interest}

The authors declare no conflict of interest.

\section{Reference}

1. Jemal, A.; Siegel, R.; Xu, J.; Ward, E. Cancer statistics, 2010. CA Cancer J. Clin. 2010, 60, 277-300.

2. $\quad$ Broers, J.L.; Rot, M.K.; Oostendorp, T.; Huysmans, A.; Wagenaar, S.S.; Wiersma-van Tilburg, A.J.; Vooijs, G.P.; Ramaekers, F.C. Immunocytochemical detection of human lung cancer heterogeneity using antibodies to epithelial, neuronal, and neuroendocrine antigens. Cancer Res. 1987, 47, 3225-3234.

3. Mukherjee, T.K.; Paul, K.; Mukhopadhyay, S. Cell signaling molecules as drug targets in lung cancer: An overview. Curr. Opin. Pulm. Med. 2011, 17, 286-291.

4. Larsen, J.E.; Cascone, T.; Gerber, D.E.; Heymach, J.V.; Minna, J.D. Targeted therapies for lung cancer: Clinical experience and novel agents. Cancer J. 2011, 17, 512-527.

5. Warburton, D.; El-Hashash, A.; Carraro, G.; Tiozzo, C.; Sala, F.; Rogers, O.; De Langhe, S.; Kemp, P.J.; Riccardi, D.; Torday, J.; et al. Lung organogenesis. Curr. Top. Dev. Biol. 2010, 90, 73-158.

6. Dang, X.; Ma, A.; Yang, L.; Hu, H.; Zhu, B.; Shang, D.; Chen, T.; Luo, Y. Microrna-26a regulates tumorigenic properties of ezh2 in human lung carcinoma cells. Cancer Genet. 2012, 205, 113-123.

7. Lee, S.; Kim, Y.; Sun, J.M.; Choi, Y.L.; Kim, J.G.; Shim, Y.M.; Park, Y.H.; Ahn, J.S.; Park, K.; Han, J.H.; et al. Molecular profiles of egfr, k-ras, c-met, and fgfr in pulmonary pleomorphic carcinoma, a rare lung malignancy. J. Cancer Res. Clin. Oncol. 2011, 137, 1203-1211. 
8. Chang, Y.L.; Wu, C.T.; Shih, J.Y.; Lee, Y.C. Egfr and p53 status of pulmonary pleomorphic carcinoma: Implications for egfr tyrosine kinase inhibitors therapy of an aggressive lung malignancy. Ann. Surg. Oncol. 2011, 18, 2952-2960.

9. Wen, J.; Fu, J.; Zhang, W.; Guo, M. Genetic and epigenetic changes in lung carcinoma and their clinical implications. Mod. Pathol. 2011, 24, 932-943.

10. Schepers, G.E.; Teasdale, R.D.; Koopman, P. Twenty pairs of Sox: Extent, homology, and nomenclature of the mouse and human Sox transcription factor gene families. Dev. Cell 2002, 3, $167-170$.

11. Kormish, J.D.; Sinner, D.; Zorn, A.M. Interactions between Sox factors and wnt/beta-catenin signaling in development and disease. Dev. Dyn. 2010, 239, 56-68.

12. Bowles, J.; Schepers, G.; Koopman, P. Phylogeny of the Sox family of developmental transcription factors based on sequence and structural indicators. Dev. Biol. 2000, 227, 239-255.

13. Mertin, S.; McDowall, S.G.; Harley, V.R. The DNA-binding specificity of Sox 9 and other Sox proteins. Nucleic Acids Res. 1999, 27, 1359-1364.

14. Van Beest, M.; Dooijes, D.; van De Wetering, M.; Kjaerulff, S.; Bonvin, A.; Nielsen, O.; Clevers, H. Sequence-specific high mobility group box factors recognize 10-12-base pair minor groove motifs. J. Biol. Chem. 2000, 275, 27266-27273.

15. Harley, V.R.; Lovell-Badge, R.; Goodfellow, P.N. Definition of a consensus DNA binding site for sry. Nucleic Acids Res. 1994, 22, 1500-1501.

16. Tanaka, S.; Kamachi, Y.; Tanouchi, A.; Hamada, H.; Jing, N.; Kondoh, H. Interplay of Sox and pou factors in regulation of the nestin gene in neural primordial cells. Mol. Cell. Biol. 2004, 24, 8834-8846.

17. Wissmuller, S.; Kosian, T.; Wolf, M.; Finzsch, M.; Wegner, M. The high-mobility-group domain of Sox proteins interacts with DNA-binding domains of many transcription factors. Nucleic Acids Res. 2006, 34, 1735-1744.

18. Chen, Q.L.; Zheng, W.L.; Yao, W.J.; Nie, L.W.; Cheng, S.H.; Ma, W.L. Analysis of Sox4 gene mutation in non-small cell lung cancer tissues. Zhonghua Yi Xue Yi Chuan Xue Za Zhi 2007, 24, 505-509.

19. Castillo, S.D.; Sanchez-Cespedes, M. The Sox family of genes in cancer development: Biological relevance and opportunities for therapy. Expert Opin. Ther. Targets 2012, 16, 903-919.

20. Dong, C.; Wilhelm, D.; Koopman, P. Sox genes and cancer. Cytogen. Genome Res. 2004, 105, $442-447$.

21. Melichar, H.J.; Narayan, K.; Der, S.D.; Hiraoka, Y.; Gardiol, N.; Jeannet, G.; Held, W.; Chambers, C.A.; Kang, J. Regulation of gammadelta versus alphabeta $\mathrm{T}$ lymphocyte differentiation by the transcription factor Sox13. Science 2007, 315, 230-233.

22. Fernandez-Lloris, R.; Osses, N.; Jaffray, E.; Shen, L.N.; Vaughan, O.A.; Girwood, D.; Bartrons, R.; Rosa, J.L.; Hay, R.T.; Ventura, F. Repression of Sox6 transcriptional activity by sumo modification. FEBS Lett. 2006, 580, 1215-1221.

23. Pan, X.; Li, H.; Zhang, P.; Jin, B.; Man, J.; Tian, L.; Su, G.; Zhao, J.; Li, W.; Liu, H.; et al. Ubc9 interacts with Sox 4 and represses its transcriptional activity. Biochem. Biophys. Res. Commun. 2006, 344, 727-734. 
24. Kaplan, F. Molecular determinants of fetal lung organogenesis. Mol. Genet. Metab. 2000, 71, 321-341.

25. Lange, A.W.; Keiser, A.R.; Wells, J.M.; Zorn, A.M.; Whitsett, J.A. Sox17 promotes cell cycle progression and inhibits tgf-beta/smad3 signaling to initiate progenitor cell behavior in the respiratory epithelium. PLoS One 2009, 4, e5711.

26. Park, J.; Zhang, J.J.; Moro, A.; Kushida, M.; Wegner, M.; Kim, P.C. Regulation of Sox9 by sonic hedgehog (shh) is essential for patterning and formation of tracheal cartilage. Dev. Dyn. 2010, 239, 514-526.

27. Park, K.S.; Wells, J.M.; Zorn, A.M.; Wert, S.E.; Whitsett, J.A. Sox17 influences the differentiation of respiratory epithelial cells. Dev. Biol. 2006, 294, 192-202.

28. Tompkins, D.H.; Besnard, V.; Lange, A.W.; Keiser, A.R.; Wert, S.E.; Bruno, M.D.; Whitsett, J.A. Sox2 activates cell proliferation and differentiation in the respiratory epithelium. Am. J. Respir. Cell Mol. Biol. 2011, 45, 101-110.

29. Sock, E.; Rettig, S.D.; Enderich, J.; Bosl, M.R.; Tamm, E.R.; Wegner, M. Gene targeting reveals a widespread role for the high-mobility-group transcription factor Sox11 in tissue remodeling. Mol. Cell. Biol. 2004, 24, 6635-6644.

30. Gontan, C.; de Munck, A.; Vermeij, M.; Grosveld, F.; Tibboel, D.; Rottier, R. Sox2 is important for two crucial processes in lung development: Branching morphogenesis and epithelial cell differentiation. Dev. Biol. 2008, 317, 296-309.

31. Tompkins, D.H.; Besnard, V.; Lange, A.W.; Wert, S.E.; Keiser, A.R.; Smith, A.N.; Lang, R.; Whitsett, J.A. Sox 2 is required for maintenance and differentiation of bronchiolar clara, ciliated, and goblet cells. PLoS One 2009, 4, e8248.

32. Que, J.; Luo, X.; Schwartz, R.J.; Hogan, B.L. Multiple roles for Sox2 in the developing and adult mouse trachea. Development 2009, 136, 1899-1907.

33. Elluru, R.G.; Thompson, F.; Reece, A. Fibroblast growth factor 18 gives growth and directional cues to airway cartilage. Laryngoscope 2009, 119, 1153-1165.

34. Perl, A.K.; Kist, R.; Shan, Z.; Scherer, G.; Whitsett, J.A. Normal lung development and function after Sox9 inactivation in the respiratory epithelium. Genesis 2005, 41, 23-32.

35. Park, K.S.; Wells, J.M.; Zorn, A.M.; Wert, S.E.; Laubach, V.E.; Fernandez, L.G.; Whitsett, J.A. Transdifferentiation of ciliated cells during repair of the respiratory epithelium. Am. J. Respir. Cell Mol. Biol. 2006, 34, 151-157.

36. Yin, D.; Jia, Y.; Yu, Y.; Brock, M.V.; Herman, J.G.; Han, C.; Su, X.; Liu, Y.; Guo, M. Sox17 methylation inhibits its antagonism of wnt signaling pathway in lung cancer. Discovery Med. 2012, 14, 33-40.

37. Seguin, C.A.; Draper, J.S.; Nagy, A.; Rossant, J. Establishment of endoderm progenitors by Sox transcription factor expression in human embryonic stem cells. Cell Stem Cell 2008, 3, 182-195.

38. Kim, I.; Saunders, T.L.; Morrison, S.J. Sox17 dependence distinguishes the transcriptional regulation of fetal from adult hematopoietic stem cells. Cell 2007, 130, 470-483.

39. Matsui, T.; Kanai-Azuma, M.; Hara, K.; Matoba, S.; Hiramatsu, R.; Kawakami, H.; Kurohmaru, M.; Koopman, P.; Kanai, Y. Redundant roles of Sox17 and Sox 18 in postnatal angiogenesis in mice. J. Cell Sci. 2006, 119, 3513-3526. 
40. Sakamoto, Y.; Hara, K.; Kanai-Azuma, M.; Matsui, T.; Miura, Y.; Tsunekawa, N.; Kurohmaru, M.; Saijoh, Y.; Koopman, P.; Kanai, Y. Redundant roles of Sox17 and Sox 18 in early cardiovascular development of mouse embryos. Biochem. Biophys. Res. Commun. 2007, 360, 539-544.

41. Otsubo, T.; Akiyama, Y.; Yanagihara, K.; Yuasa, Y. Sox2 is frequently downregulated in gastric cancers and inhibits cell growth through cell-cycle arrest and apoptosis. Br. J. Cancer 2008, 98, 824-831.

42. Sun, M.; Uozaki, H.; Hino, R.; Kunita, A.; Shinozaki, A.; Ushiku, T.; Hibiya, T.; Takeshita, K.; Isogai, M.; Takada, K.; et al. Sox 9 expression and its methylation status in gastric cancer. Virchows Arch 2012, 460, 271-279.

43. Cox, J.L.; Wilder, P.J.; Desler, M.; Rizzino, A. Elevating Sox2 levels deleteriously affects the growth of medulloblastoma and glioblastoma cells. PLoS One 2012, 7, e44087.

44. Swartling, F.J.; Savov, V.; Persson, A.I.; Chen, J.; Hackett, C.S.; Northcott, P.A.; Grimmer, M.R.; Lau, J.; Chesler, L.; Perry, A.; et al. Distinct neural stem cell populations give rise to disparate brain tumors in response to n-myc. Cancer Cell 2012, 21, 601-613.

45. Burgos-Ojeda, D.; Rueda, B.R.; Buckanovich, R.J. Ovarian cancer stem cell markers: Prognostic and therapeutic implications. Cancer Lett. 2012, 322, 1-7.

46. Jiang, S.S.; Fang, W.T.; Hou, Y.H.; Huang, S.F.; Yen, B.L.; Chang, J.L.; Li, S.M.; Liu, H.P.; Liu, Y.L.; Huang, C.T.; et al. Upregulation of Sox9 in lung adenocarcinoma and its involvement in the regulation of cell growth and tumorigenicity. Clin. Cancer Res. 2010, 16, 4363-4373.

47. Li, B.; Ge, Z.; Song, S.; Zhang, S.; Yan, H.; Huang, B.; Zhang, Y. Decreased expression of Sox7 is correlated with poor prognosis in lung adenocarcinoma patients. Pathol. Oncol. Res. 2012, 18, 1039-1045.

48. Sholl, L.M.; Barletta, J.A.; Yeap, B.Y.; Chirieac, L.R.; Hornick, J.L. Sox2 protein expression is an independent poor prognostic indicator in stage i lung adenocarcinoma. Am. J. Surg. Pathol. 2010, 34, 1193-1198.

49. Yousem, S.A. Role of molecular studies in the diagnosis of lung adenocarcinoma. Mod. Pathol. 2012, 25, S11-S17.

50. Guo, X.; Xiong, L.; Sun, T.; Peng, R.; Zou, L.; Zhu, H.; Zhang, J.; Li, H.; Zhao, J. Expression features of Sox9 associate with tumor progression and poor prognosis of hepatocellular carcinoma. Diagn. Pathol. 2012, 7, 44.

51. Chen, Y.; Shi, L.; Zhang, L.; Li, R.; Liang, J.; Yu, W.; Sun, L.; Yang, X.; Wang, Y.; Zhang, Y.; et al. The molecular mechanism governing the oncogenic potential of Sox2 in breast cancer. $J$ Biol. Chem. 2008, 283, 17969-17978.

52. Fu, D.Y.; Wang, Z.M.; Li, C.; Wang, B.L.; Shen, Z.Z.; Huang, W.; Shao, Z.M. Sox17, the canonical wnt antagonist, is epigenetically inactivated by promoter methylation in human breast cancer. Breast Cancer Res. Treat. 2009, 119, 601-612.

53. Acloque, H.; Ocana, O.H.; Matheu, A.; Rizzoti, K.; Wise, C.; Lovell-Badge, R.; Nieto, M.A. Reciprocal repression between Sox 3 and snail transcription factors defines embryonic territories at gastrulation. Dev. Cell 2011, 21, 546-558.

54. Passeron, T.; Valencia, J.C.; Namiki, T.; Vieira, W.D.; Passeron, H.; Miyamura, Y.; Hearing, V.J. Upregulation of Sox 9 inhibits the growth of human and mouse melanomas and restores their sensitivity to retinoic acid. J. Clin. Invest. 2009, 119, 954-963. 
55. Liu, P.; Ramachandran, S.; Ali Seyed, M.; Scharer, C.D.; Laycock, N.; Dalton, W.B.; Williams, H.; Karanam, S.; Datta, M.W.; Jaye, D.L.; et al. Sex-determining region y box 4 is a transforming oncogene in human prostate cancer cells. Cancer Res. 2006, 66, 4011-4019.

56. Scharer, C.D.; McCabe, C.D.; Ali-Seyed, M.; Berger, M.F.; Bulyk, M.L.; Moreno, C.S. Genome-wide promoter analysis of the Sox4 transcriptional network in prostate cancer cells. Cancer Res. 2009, 69, 709-717.

57. Wang, H.; McKnight, N.C.; Zhang, T.; Lu, M.L.; Balk, S.P.; Yuan, X. Sox9 is expressed in normal prostate basal cells and regulates androgen receptor expression in prostate cancer cells. Cancer Res. 2007, 67, 528-536.

58. Zhong, W.D.; Qin, G.Q.; Dai, Q.S.; Han, Z.D.; Ling, X.H.; Fu, X.; Cai, C.; Chen, J.H.; Chen, X.B.; Lin, Z.Y.; et al. Soxs in human prostate cancer: Implication as progression and prognosis factors. BMC Cancer 2012, 12, 248.

59. Sinner, D.; Kordich, J.J.; Spence, J.R.; Opoka, R.; Rankin, S.; Lin, S.C.; Jonatan, D.; Zorn, A.M.; Wells, J.M. Sox17 and Sox4 differentially regulate beta-catenin/T-cell factor activity and proliferation of colon carcinoma cells. Mol. Cell. Biol. 2007, 27, 7802-7815.

60. Azhikina, T.; Kozlova, A.; Skvortsov, T.; Sverdlov, E. Heterogeneity and degree of timp4, gata4, Sox18, and egfl7 gene promoter methylation in non-small cell lung cancer and surrounding tissues. Cancer Genet. 2011, 204, 492-500.

61. Castillo, S.D.; Matheu, A.; Mariani, N.; Carretero, J.; Lopez-Rios, F.; Lovell-Badge, R.; Sanchez-Cespedes, M. Novel transcriptional targets of the sry-HMG box transcription factor Sox 4 link its expression to the development of small cell lung cancer. Cancer Res. 2012, 72, 176-186.

62. Chen, S.; Xu, Y.; Chen, Y.; Li, X.; Mou, W.; Wang, L.; Liu, Y.; Reisfeld, R.A.; Xiang, R.; Lv, D.; et al. Sox2 gene regulates the transcriptional network of oncogenes and affects tumorigenesis of human lung cancer cells. PLoS One 2012, 7, e36326.

63. Li, X.; Wang, J.; Xu, Z.; Ahmad, A.; Li, E.; Wang, Y.; Qin, S.; Wang, Q. Expression of Sox2 and Oct4 and their clinical significance in human non-small-cell lung cancer. Int. J. Mol. Sci. 2012, 13, 7663-7675.

64. Maddison, P.; Thorpe, A.; Silcocks, P.; Robertson, J.F.; Chapman, C.J. Autoimmunity to Sox2, clinical phenotype and survival in patients with small-cell lung cancer. Lung Cancer 2010, 70, 335-339.

65. Medina, P.P.; Castillo, S.D.; Blanco, S.; Sanz-Garcia, M.; Largo, C.; Alvarez, S.; Yokota, J.; Gonzalez-Neira, A.; Benitez, J.; Clevers, H.C.; et al. The sry-HMG box gene, Sox4, is a target of gene amplification at chromosome $6 \mathrm{p}$ in lung cancer. Hum. Mol. Genet. 2009, 18, 1343-1352.

66. Rudin, C.M.; Durinck, S.; Stawiski, E.W.; Poirier, J.T.; Modrusan, Z.; Shames, D.S.; Bergbower, E.A.; Guan, Y.; Shin, J.; Guillory, J.; et al. Comprehensive genomic analysis identifies Sox2 as a frequently amplified gene in small-cell lung cancer. Nat. Genet. 2012, 44, 1111-1116.

67. Titulaer, M.J.; Klooster, R.; Potman, M.; Sabater, L.; Graus, F.; Hegeman, I.M.; Thijssen, P.E.; Wirtz, P.W.; Twijnstra, A.; Smitt, P.A.; et al. Sox antibodies in small-cell lung cancer and lambert-eaton myasthenic syndrome: Frequency and relation with survival. J. Clin. Oncol. 2009, 27, 4260-4267. 
68. Wilbertz, T.; Wagner, P.; Petersen, K.; Stiedl, A.C.; Scheble, V.J.; Maier, S.; Reischl, M.; Mikut, R.; Altorki, N.K.; Moch, H.; et al. Sox2 gene amplification and protein overexpression are associated with better outcome in squamous cell lung cancer. Mod. Pathol. 2011, 24, 944-953.

69. Xiang, R.; Liao, D.; Cheng, T.; Zhou, H.; Shi, Q.; Chuang, T.S.; Markowitz, D.; Reisfeld, R.A.; Luo, Y. Downregulation of transcription factor Sox 2 in cancer stem cells suppresses growth and metastasis of lung cancer. Br. J. Cancer 2011, 104, 1410-1417.

70. Wang, L.; He, S.; Yuan, J.; Mao, X.; Cao, Y.; Zong, J.; Tu, Y.; Zhang, Y. Oncogenic role of Sox9 expression in human malignant glioma. Med. Oncol. 2012, doi:10.1007/s12032-012-0267-z.

71. Yan, H.T.; Shinka, T.; Sato, Y.; Yang, X.J.; Chen, G.; Sakamoto, K.; Kinoshita, K.; Aburatani, H.; Nakahori, Y. Overexpression of Sox15 inhibits proliferation of $\mathrm{nt} 2 / \mathrm{d} 1$ cells derived from a testicular embryonal cell carcinoma. Mol. Cells 2007, 24, 323-328.

72. Aleman, A.; Adrien, L.; Lopez-Serra, L.; Cordon-Cardo, C.; Esteller, M.; Belbin, T.J.; Sanchez-Carbayo, M. Identification of DNA hypermethylation of Sox 9 in association with bladder cancer progression using cpg microarrays. Br. J. Cancer 2008, 98, 466-473.

73. Matheu, A.; Collado, M.; Wise, C.; Manterola, L.; Cekaite, L.; Tye, A.J.; Canamero, M.; Bujanda, L.; Schedl, A.; Cheah, K.S.; et al. Oncogenicity of the developmental transcription factor Sox9. Cancer Res. 2012, 72, 1301-1315.

74. Alonso, M.M.; Diez-Valle, R.; Manterola, L.; Rubio, A.; Liu, D.; Cortes-Santiago, N.; Urquiza, L.; Jauregi, P.; Lopez de Munain, A.; Sampron, N.; et al. Genetic and epigenetic modifications of Sox 2 contribute to the invasive phenotype of malignant gliomas. PLoS One 2011, 6, e26740.

75. Cai, Y.R.; Zhang, H.Q.; Qu, Y.; Mu, J.; Zhao, D.; Zhou, L.J.; Yan, H.; Ye, J.W.; Liu, Y. Expression of met and Sox2 genes in non-small cell lung carcinoma with egfr mutation. Oncol. Rep. 2011, 26, 877-885.

76. Yuan, P.; Kadara, H.; Behrens, C.; Tang, X.; Woods, D.; Solis, L.M.; Huang, J.; Spinola, M.; Dong, W.; Yin, G.; et al. Sex determining region y-box 2 (Sox2) is a potential cell-lineage gene highly expressed in the pathogenesis of squamous cell carcinomas of the lung. PLoS One 2010, 5, e9112.

77. Sabater, L.; Titulaer, M.; Saiz, A.; Verschuuren, J.; Gure, A.O.; Graus, F. Sox1 antibodies are markers of paraneoplastic lambert-eaton myasthenic syndrome. Neurology 2008, 70, 924-928.

78. Gure, A.O.; Stockert, E.; Scanlan, M.J.; Keresztes, R.S.; Jager, D.; Altorki, N.K.; Old, L.J.; Chen, Y.T. Serological identification of embryonic neural proteins as highly immunogenic tumor antigens in small cell lung cancer. Proc. Natl. Acad. Sci. USA 2000, 97, 4198-4203.

79. Vural, B.; Chen, L.C.; Saip, P.; Chen, Y.T.; Ustuner, Z.; Gonen, M.; Simpson, A.J.; Old, L.J.; Ozbek, U.; Gure, A.O. Frequency of Sox group b (Sox1, 2, 3) and zic2 antibodies in turkish patients with small cell lung carcinoma and their correlation with clinical parameters. Cancer 2005, 103, 2575-2583.

80. Lu, Y.; Futtner, C.; Rock, J.R.; Xu, X.; Whitworth, W.; Hogan, B.L.; Onaitis, M.W. Evidence that Sox 2 overexpression is oncogenic in the lung. PLoS One 2010, 5, e11022.

81. Friedman, R.S.; Bangur, C.S.; Zasloff, E.J.; Fan, L.; Wang, T.; Watanabe, Y.; Kalos, M. Molecular and immunological evaluation of the transcription factor Sox 4 as a lung tumor vaccine antigen. J. Immunol. 2004, 172, 3319-3327. 
82. D'Angelo, S.P.; Pietanza, M.C. The molecular pathogenesis of small cell lung cancer. Cancer Biol. Ther. 2010, 10, 1-10.

83. Sholl, L.M.; Long, K.B.; Hornick, J.L. Sox2 expression in pulmonary non-small cell and neuroendocrine carcinomas. Appl. Immunohistochem. Mol. Morphol. 2010, 18, 55-61.

84. Bass, A.J.; Watanabe, H.; Mermel, C.H.; Yu, S.; Perner, S.; Verhaak, R.G.; Kim, S.Y.; Wardwell, L.; Tamayo, P.; Gat-Viks, I.; et al. Sox2 is an amplified lineage-survival oncogene in lung and esophageal squamous cell carcinomas. Nat. Genet. 2009, 41, 1238-1242.

85. Aaboe, M.; Birkenkamp-Demtroder, K.; Wiuf, C.; Sorensen, F.B.; Thykjaer, T.; Sauter, G.; Jensen, K.M.; Dyrskjot, L.; Orntoft, T. Sox4 expression in bladder carcinoma: Clinical aspects and in vitro functional characterization. Cancer Res. 2006, 66, 3434-3442.

86. Beer, D.G.; Kardia, S.L.; Huang, C.C.; Giordano, T.J.; Levin, A.M.; Misek, D.E.; Lin, L.; Chen, G.; Gharib, T.G.; Thomas, D.G.; et al. Gene-expression profiles predict survival of patients with lung adenocarcinoma. Nat. Med. 2002, 8, 816-824.

87. Tavazoie, S.F.; Alarcon, C.; Oskarsson, T.; Padua, D.; Wang, Q.; Bos, P.D.; Gerald, W.L.; Massague, J. Endogenous human micrornas that suppress breast cancer metastasis. Nature 2008, $451,147-152$.

88. Pramoonjago, P.; Baras, A.S.; Moskaluk, C.A. Knockdown of Sox4 expression by rnai induces apoptosis in acc3 cells. Oncogene 2006, 25, 5626-5639.

89. Dammann, R.; Strunnikova, M.; Schagdarsurengin, U.; Rastetter, M.; Papritz, M.; Hattenhorst, U.E.; Hofmann, H.S.; Silber, R.E.; Burdach, S.; Hansen, G. Cpg island methylation and expression of tumour-associated genes in lung carcinoma. Eur. J. Cancer 2005, 41, 1223-1236.

90. Fan, R.; Zhang, L.Y.; Wang, H.; Yang, B.; Han, T.; Zhao, X.L.; Wang, W.; Wang, X.Q.; Lin, G.W. Methylation of the cpg island near Sox7 gene promoter is correlated with the poor prognosis of patients with myelodysplastic syndrome. Tohoku J. Exp. Med. 2012, 227, 119-128.

91. Peacock, C.D.; Watkins, D.N. Cancer stem cells and the ontogeny of lung cancer. J. Clin. Oncol. 2008, 26, 2883-2889.

92. Xu, Y.; Hu, Y.D. Lung cancer stem cells research. Clues from ontogeny. Saudi Med. J. 2009, 30, 1381-1389.

93. Asselin-Labat, M.L.; Filby, C.E. Adult lung stem cells and their contribution to lung tumourigenesis. Open Biol. 2012, 2, 120094.

94. Kim, C.F.; Jackson, E.L.; Woolfenden, A.E.; Lawrence, S.; Babar, I.; Vogel, S.; Crowley, D.; Bronson, R.T.; Jacks, T. Identification of bronchioalveolar stem cells in normal lung and lung cancer. Cell 2005, 121, 823-835.

95. Park, I.H.; Zhao, R.; West, J.A.; Yabuuchi, A.; Huo, H.; Ince, T.A.; Lerou, P.H.; Lensch, M.W.; Daley, G.Q. Reprogramming of human somatic cells to pluripotency with defined factors. Nature 2008, 451, 141-146.

96. Miyoshi, N.; Ishii, H.; Nagai, K.; Hoshino, H.; Mimori, K.; Tanaka, F.; Nagano, H.; Sekimoto, M.; Doki, Y.; Mori, M. Defined factors induce reprogramming of gastrointestinal cancer cells. Proc. Natl. Acad. Sci. USA 2010, 107, 40-45.

97. Ikushima, H.; Todo, T.; Ino, Y.; Takahashi, M.; Miyazawa, K.; Miyazono, K. Autocrine TGF- $\beta$ signaling maintains tumorigenicity of glioma-initiating cells through sry-related hmg-box factors. Cell Stem Cell 2009, 5, 504-514. 
98. Neumann, J.; Bahr, F.; Horst, D.; Kriegl, L.; Engel, J.; Luque, R.M.; Gerhard, M.; Kirchner, T.; Jung, A. Sox2 expression correlates with lymph-node metastases and distant spread in right-sided colon cancer. BMC Cancer 2011, 11, 518.

99. Giangreco, A.; Lu, L.; Vickers, C.; Teixeira, V.H.; Groot, K.R.; Butler, C.R.; Ilieva, E.V.; George, P.J.; Nicholson, A.G.; Sage, E.K.; et al. Beta-catenin determines upper airway progenitor cell fate and preinvasive squamous lung cancer progression by modulating epithelial-mesenchymal transition. J. Pathol. 2012, 226, 575-587.

100. Clevers, H. Wnt/ $\beta$-catenin signaling in development and disease. Cell 2006, 127, 469-480.

101. Logan, C.Y.; Nusse, R. The wnt signaling pathway in development and disease. Annu. Rev. Cell Dev. Biol. 2004, 20, 781-810.

102. Pacheco-Pinedo, E.C.; Morrisey, E.E. Wnt and Kras signaling-dark siblings in lung cancer. Oncotarget 2011, 2, 569-574.

103. Pacheco-Pinedo, E.C.; Durham, A.C.; Stewart, K.M.; Goss, A.M.; Lu, M.M.; Demayo, F.J.; Morrisey, E.E. Wnt/ $\beta$-catenin signaling accelerates mouse lung tumorigenesis by imposing an embryonic distal progenitor phenotype on lung epithelium. J. Clin. Invest. 2011, 121, 1935-1945.

104. Tsuta, K.; Tanabe, Y.; Yoshida, A.; Takahashi, F.; Maeshima, A.M.; Asamura, H.; Tsuda, H. Utility of 10 immunohistochemical markers including novel markers (desmocollin-3, glypican 3, s100a2, s100a7, and Sox2) for differential diagnosis of squamous cell carcinoma from adenocarcinoma of the lung. J. Thorac. Oncol. 2011, 6, 1190-1199.

(C) 2012 by the authors; licensee MDPI, Basel, Switzerland. This article is an open access article distributed under the terms and conditions of the Creative Commons Attribution license (http://creativecommons.org/licenses/by/3.0/). 